CASSOWARY volume 4 (2) Juni 2021: 159-171

ISSN : 2614-8900

E-ISSN : 2622-6545

CProgram Pascasarjana Universitas Papua, https://pasca.unipa.ac.id/

\title{
Analisis Kasus Stunting dan Faktor-faktor yang Berhubungan di Kampung Arowi Distrik Manokwari Timur
}

\author{
Suryana Widiastuti*, Meike Meilan Lisangan, Ludia T. Wambrauw \\ Program Studi Magister Ilmu Lingkungan Universitas Papua, Jl. Gunung Salju Amban \\ Manokwari, 98314, Papua Barat, Indonesia \\ *Email: anton_sineri@yahoo.com
}

\begin{abstract}
West Papua Province currently ranks 27 out of 34 Provisni in Indonesia with the prevalence of stunting cases. There are 3,141 children in West Papua with nutritional status with stunting in very short conditions, and 329 of them are in Manokwari Regency. East Manokwari District is one of the districts that has high stunting cases in Manokwari Regency. The purpose of this study was to determine the number of stunting cases in Arowi Village, East Manokwari District. The research method used in this research is quantitative descriptive method, which is a form of research based on data collected during research systematically regarding the facts, levels of participation and factors that influence in the East Manokwari district in Arowi village which will then be interpreted and tested based on theories and literatures. Based on the research on stunting cases in Arowi Village, it can be concluded that the number of stunting cases in Arowi Village, East Manokwari District reached 18\% of the total number of respondents. The highest cases of stunting were found in the respondent population who had low knowledge of nutrition and in children who often experienced infectious diseases.
\end{abstract}

Keywords: Stunting, Stunting in Manokwari, Stunting Prevalence in Manokwari

\section{PENDAHULUAN}

Keberhasilan pembangunan nasional dapat tercapai apabila didukung oleh terciptanya sumberdaya manusia yang handal, yaitu sumberdaya manusia Indonesia yang dapat bersaing di tingkat nasional dan global. Untuk menciptakan sumberdaya tersebut dibutuhkan komitmen baik pada tataran pemerintah pusat dan daerah maupun pada lingkup rumah tangga. Dengan demikian yang perlu menjadi perhatian pemerintah pada satuan terendah adalah peningkatan kemampuan keluarga dalam membentuk keluarga yang sehat dan sejahtera.

Indikator capaian untuk menuju Indonesia sehat ke lima yaitu balita mendapat pemantauan pertumbuhan sangat penting untuk menciptakan masa depan Indonesia. Hal ini terkait dengan masalah yang dihadapi Indonesia yang merupakan satu negara dengan triple ganda permasalahan gizi yaitu stunting, wasting dan overweight. Kondisi Stunting adalah suatu kondisi kurang gizi kronis yang disebabkan oleh kurangnya asupan gizi dalam jangka waktu cukup lama akibat pemberian makanan tidak sesuai dengan kebutuhan gizi (Millennium Challenge Account, 2014). Kekurangan gizi pada usia dini dapat menyebabkan penderitanya mudah sakit dan memiliki postur tubuh tidak maksimal saat dewasa, serta kemampuan kognitifnya berkurang. 
Keadaan ini mengakibatkan kerugian ekonomi Indonesia dalam jangka panjang.

Stunting di Indonesia saat ini masih menjadi permasalahan kesehatan dengan prevalensi nasional sebesar 20,1\% (Anon, 2018). Berdasarkan data Riset Kesehatan Dasar (Riskesdas) (Kemenkes RI, 2013), diketahui bahwa prevalensi kejadian stunting secara nasional adalah 37,2\%, dan Papua Barat berada pada urutan ke-27 dari 34 provinsi dengan kejadian $>40 \%$.

Jumlah anak Indonesia dengan status gizi stunting pada kondisi sangat pendek sebanyak 1.310.847 anak, dan Papua Barat sebanyak $3.141 \quad(0,24 \%)$. Sedangkan jumlah anak dengan stunting di Kabupaten Manokwari sebanyak 329 anak (Data Dinas Kesehatan Papua Barat, 2019). Semakin tinggi jumlah anak dengan kondisi stunting, maka semakin besar beban negara pada masa yang akan datang. Kondisi ini menyebabkan generasi yang tidak mampu bersaing dalam kancah percaturan dunia, karena stunting berhubungan dengan menurunnya kualitas sumberdaya manusia, selanjutnya menyebabkan tingkat produktivitas dan daya saing menjadi rendah.

Distrik Manokwari Timur merupakan salah satu distrik yang memiliki kasus stunting termasuk kategori tinggi di Kabupaten Manokwari. Menurut data Dinas Kesehatan Kabupaten Manokwari kasus stunting di distrik Manokwari Timur pada tahun 2019 sebesar 42,57 persen atau berada diatas persentasi Kabupaten Manokwari. Penelitian ini bertujuan untuk mengetahui jumlah kasus stunting di Kampung Arowi, Distrik Manokwari Timur.

\section{MATERI DAN METODE}

Penelitian ini dilakukan selama 1 (satu) bulan yakni Bulan September
2020, di Distrik Manokwari Timur. Pemilihan lokasi berdasarkan penetapan wilayah sasaran stunting dari Kementrian Kesehatan Republik Indonesia yakni Distrik Manokwari Timur merupakan salah 1 wilayah di Kabupaten Manokwari yang memiliki kasus stunting, dan Kampung Arowi menjadi lokus intervensi stunting baik oleh Dinas Kesehatan Kabupaten maupun sektor terkait lainnya.

Penelitian ini bersifat deskriptif kuantitatif dengan metode analisis dan survey. Responden dalam penelitian ini adalah Ibu di Kampung Arowi yang mempunyai bayi berumur 0-2 tahun, yakni sebanyak 100 orang, dengan jumlah bayi sebanyak 157 orang. Sampel dalam penelitian ini diambil dengan metode purposive sampling oleh karena dipilih berdasarkan ciri tertentu yakni Pasangan Usia Subur (PUS) yang memiliki bayi berusia $0-2$ tahun.

Jenis data dalam penelitian ini adalah data primer dan data sekunder. Data primer diperoleh dari hasil wawancara terhadap responden berdasarkan kuisioner yang telah disiapkan. Sedangkan data sekunder diperoleh dari Instansi terkait dengan pokok bahasan penelitian, antara lain Dinas Kesehatan, BKKBN, dan Bappeda kabupaten Manokwari.

Data yang telah diperoleh dari penelitian ini kemudian dianalisis dengan menggunakan program aplikasi pengolah data statistik 16.0. Analisis data pada penelitian ini menggunakan analisis data univariat. Analisis univariat dilakukan untuk menggambarkan distribusi frekuensi rata-rata, baik variabel bebas, variabel terikat, maupun deskripsi karakteristik responden. Pada analisis univariat, data yang diperoleh dari hasil pengumpulan data disajikan dalam bentuk tabel distribusi frekuensi, ukuran tendensi sentral atau grafik. Variabel independen atau variabel bebas dalam 
Tinggi Badan ibu dalam penelitian ini dikatagorikan menjadi 2 (dua), tinggi badan ibu $<150 \mathrm{~cm}$ dan tinggi ibu $\geq 150 \mathrm{~cm}$. Tinggi badan ibu di katakan normal apabila tinggi badan ibu yaitu $\geq 150 \mathrm{~cm}$.
Berikut merupakan gambaran tinggi badan Ibu yang mempunyai anak usia $0-$ 24 bulan di wilayah Kampung Arowi Distrik Manokwari Timur Tahun 2020.

Tabel 2. Distribusi Karakteristik Responden Berdasarkan Tinggi Badan Ibu

\begin{tabular}{lcccccc}
\hline \multirow{2}{*}{$\begin{array}{c}\text { Kategori Tinggi Badan } \\
\text { Ibu }\end{array}$} & \multicolumn{2}{c}{ Stunting } & \multicolumn{2}{c}{ Normal } & \multicolumn{2}{c}{ Total } \\
\cline { 2 - 7 } & $\mathbf{J m l}$ & $\mathbf{( \% )}$ & $\mathbf{J m l}$ & $\mathbf{( \% )}$ & Jml & $(\boldsymbol{\%})$ \\
\hline Normal $(\geq 150 \mathrm{~cm})$ & 6 & 35.3 & 11 & 64.7 & 17 & 28.0 \\
Tidak Normal $(<150 \mathrm{~cm})$ & 5 & 11.4 & 39 & 88.6 & 44 & 72.0 \\
\hline Total & $\mathbf{1 1}$ & $\mathbf{1 8 . 0}$ & $\mathbf{5 0}$ & $\mathbf{8 2 . 0}$ & $\mathbf{6 1}$ & $\mathbf{1 0 0 . 0}$ \\
\hline
\end{tabular}

Tabel 2 menunjukkan bahwa dari 61 Responden, 44 orang (72\%) responden memiliki tinggi badan tidak normal, sedangkan 17 orang (28\%) memiliki tinggi badan yang normal. Tabel tersebut juga menunjukan bahwa persentase kasus stunting lebih tinggi terjadi pada ibu dengan tinggi badan normal $(35,3 \%)$, sedangkan pada ibu yang memiliki tinggi badan tidak normal, hanya terjadi $11.4 \%$ kasus stunting. Tinggi badan ibu memang berpengaruh terhadap tinggi badan anak, namun hal tersebut tidak $100 \%$ menjadi sebuah penyebab terjadinya stunting. Orangtua dengan tinggi badan pendek jika tetap memberikan asupan nutrisi yang baik untuk anak bisa memberikan peluang anak ikut bertambah tinggi dan terhindar dari stunting.

Soetjiningsih (2010) menyatakan bahwa terdapat dua faktor yang mempengaruhi tumbuh kembang anak yaitu faktor genetik dan lingkungan. Gangguan pertumbuhan di negara maju lebih sering diakibatkan oleh faktor ge- netik, sedangkan di negara yang berkembang, diakibatkan oleh faktor genetik, juga faktor lingkungan yang kurang memadai untuk tumbuh kembang anak yang optimal.

\section{Karakteristik Berdasarkan Pendidikan \\ Responden}

Tingkat pendidikan seorang ibu akan mempengaruhi tingkat konsumsi pangan seseorang dalam memilih bahan pangan demi memenuhi kebutuhan hidupnya. Orang yang memiliki pendidikan tinggi akan cenderung memilih bahan pangan yang lebih baik dalam kuantitas maupun kualitas dibandingkan dengan orang yang berpendidikan rendah.

Tingkat Pendidikan Ibu dalam penelitian ini dikatagorikan menjadi 4 (empat), yaitu tingkat pendidikan SD, SLTP, SLTA dan DIPLOMA/PT. Berikut sebaran Tingkat Pendidkan Ibu yang mempunyai anak pada usia $0-24$ bulan di Kampung Arowi Distrik Manokwari Timur Tahun 2020.

Tabel 3. Distribusi Karakteristik Responden Berdasarkan Pendidikan Ibu

\begin{tabular}{lcccccc}
\hline Kategori Tingkat & \multicolumn{2}{c}{ Stunting } & \multicolumn{2}{c}{ Normal } & \multicolumn{2}{c}{ Total } \\
\cline { 2 - 7 } Pendidikan Ibu & $\mathbf{J m l}$ & $\mathbf{( \% )}$ & $\mathbf{J m l}$ & $\mathbf{( \% )}$ & $\mathbf{J m l}$ & $(\boldsymbol{\%})$ \\
\hline SD & 8 & 66.7 & 4 & 33.3 & 12 & 19.7 \\
SLTP & 2 & 18.2 & 9 & 81.8 & 11 & 18.0 \\
SLTA & 1 & 3.2 & 30 & 96.8 & 31 & 50.8 \\
Diploma/PT & 0 & 0.0 & 7 & 100.0 & 7 & 11.5 \\
\hline Total & $\mathbf{1 1}$ & $\mathbf{1 8 . 0}$ & $\mathbf{5 0}$ & $\mathbf{8 2 . 0}$ & $\mathbf{6 1}$ & $\mathbf{1 0 0 . 0}$ \\
\hline
\end{tabular}


Berdasarkan Tabel 3 diketahui bahwa responden didominasi oleh ibu dengan tingkat pendidikan SLTA $(50,8 \%)$, kemudian disusul oleh ibu dengan tingkat pendidikan SD $(19,7 \%)$, dan persentase paling kecil $(11,5 \%)$ adalah ibu yang memiliki tingkat pendidikan Diploma/PT. Pada ibu dengan tingkat pendidikan SD, dijumpai adanya kasus stunting sebesar $66,7 \%$, hal ini kontras jika dibandingkan dengan ibu yang memiliki tingkat pendidikan Diploma/PT. Ibu yang memiliki tingkat pendidikan Diploma/PT tidak memiliki kasus stunting.

Pendidikan orangtua merupakan salah satu faktor yang penting dalam tumbuh kembang anak. Pendidikan orang tua yang baik dapat memudahkan dalam menerima segala informasi dari luar terutama mengenai cara pengasuhan anak yang baik, cara menjaga kesehatan anak, dan lain sebagainya.

Notoatmodjo (2005) menyatakan bahwa perilaku dipengaruhi oleh sikap dan pengetahuan. Pengetahuan yang baik akan menciptakan sikap yang baik, yang selanjutnya apabila sikap tersebut dinilai sesuai, maka akan muncul perilaku yang baik pula. Pengetahuan sendiri didapatkan dari informasi baik yang didapatkan dari pendidikan formal maupun dari media (non formal), seperti radio, TV, internet, koran, majalah, dll.

\section{Karakteristik \\ Berdasarkan Pekerjaan \\ Pekerjaan Orang Tuan akan} mempengaruhi tingkat ekonomi keluarga. Pekerjaan Orang tua dalam penelitian ini di katagorikan menjadi 4 (empat), yaitu Tidak bekerja atau Tidak memiliki pekerjaan tetap, Nelayan/Petani, Wiraswasta dan ASN/TNI/POLRI. Berikut gambaran sebaran tingkat Pekerjaan orang tua pada yang memiliki anak usia $0-24$ bulan di wilayah Kampung Arowi Distrik Manokwari Timur Tahun 2020.

Tabel 4. Distribusi Karakteristik Responden Berdasarkan Pekerjaan

\begin{tabular}{lccccccc}
\hline \multicolumn{1}{c}{ Kategori Pekerjaan } & \multicolumn{2}{c}{ Stunting } & \multicolumn{2}{c}{ Normal } & \multicolumn{2}{c}{ Total } \\
\cline { 2 - 8 } Orang tua & Jml & $\mathbf{( \% )}$ & Jml & $(\%)$ & Jml & $(\%)$ \\
\hline Tidak Bekerja/ Tidak & 11 & 21.6 & 40 & 78.4 & 51 & 84.0 \\
memiliki pekerjaan tetap & & & & & & \\
Nelayan/Petani & 0 & 0.0 & 2 & 100.0 & 2 & 3.3 \\
Wiraswasta & 0 & 0.0 & 4 & 100.0 & 4 & 6.6 \\
ASN/TNI/POLRI & 0 & 0.0 & 4 & 100.0 & 4 & 6.6 \\
\hline Total & $\mathbf{1 1}$ & $\mathbf{1 8 . 0}$ & $\mathbf{5 0}$ & $\mathbf{8 2 . 0}$ & $\mathbf{6 1}$ & $\mathbf{1 0 0 . 0}$ \\
\hline
\end{tabular}

Tabel 4 menunjukkan bahwa sebagian besar responden $(78,4 \%)$ tidak memiliki pekerjaan, atau memiliki pekerjaan yang tidak tetap. Semua kasus stunting, dijumpai pada keluarga dimana orang tua tidak memiliki pekerjaan tetap atau tidak bekerja. Orang tua yang tidak bekerja atau tidak memiliki pekerjaan tetap tentunya akan mengalami kesulitan dalam mencukupi kebutuhan hidup keluarga.
Menurut Marmi (2013) Pekerjaan adalah sesuatu yang harus dilakukan terutama untuk menunjang kehidupan keluarganya. Pekerjaan orang tua merupakan kegiatan atau tindakan yang dilakukan oleh setiap orang tua untuk mendapatkan uang. Pekerjaan tersebut akan memengaruhi pendapatan keluarga, dan akhirnya akan berpengaruh pada konsumsi pangan anak 


\section{Karakteristik}

Responden

Berdasarkan Rata - rata Penghasilan

Keadaan ekonomi yang cukup dominan dalam mempengaruhi konsumsi pangan adalah pendapatan Perkapita keluarga dan harga. Meningkatnya pendapatan maka akan meningkat peluang untuk membeli pangan dengan kuantitas dan kualitas yang lebih baik, sebaliknya penurunan pendapatan akan menyebabkan menurunnya daya beli pangan. Sehingga orang tua yang menghasilkan pendapan tinggi, akan menunjang tumbuh kembang anak, karena orang tua dapat menyediakan semua kebutuhan anak baik yang primer maupun yang sekunder.

Berikut Merupakan gambaran rata rata penghasilan keluarga perbulan yang memiliki anak usia 0 - 24 bulan di wilayah Kampung Arowi Distrik Manokwari Timur Tahun 2020.

Tabel 5. Distribusi Karakteristik Responden Berdasarkan rata - rata Penghasilan keluarga

\begin{tabular}{lcccccc}
\hline \multicolumn{1}{c}{ Kategori Rata - rata } & \multicolumn{2}{c}{ Stunting } & \multicolumn{2}{c}{ Normal } & \multicolumn{2}{c}{ Total } \\
\cline { 2 - 7 } Penghasilan Keluraga & Jml & $\mathbf{( \% )}$ & Jml & $\mathbf{( \% )}$ & Jml & $(\boldsymbol{\%})$ \\
\hline$<$ Rp.500.000/Bln & 6 & 19.4 & 25 & 80.6 & 31 & 50.8 \\
Rp.500.000 - 1.500.000/bln & 5 & 25.0 & 15 & 75.0 & 20 & 32.8 \\
$>1.500 .000 /$ bln & 0 & 0.0 & 10 & 100.0 & 10 & 16.4 \\
\hline Total & $\mathbf{1 1}$ & $\mathbf{1 8 . 0}$ & $\mathbf{5 0}$ & $\mathbf{8 2 . 0}$ & $\mathbf{6 1}$ & $\mathbf{1 0 0 . 0}$ \\
\hline
\end{tabular}

Tabel 5 diketahui bahwa 50,8\% responden memiliki penghasilan kurang Rp.500.000/bln, hanya $16,4 \%$ responden yang memilikin penghasilan lebih dari Rp.1.500.000/bln. Dijumpai ada 19,4\% kasus stunting pada keluarga yang berpenghasilan kurang dari Rp.500.000/bln, dan $25 \%$ pada penghasilan antara Rp.500.000/bln sampai dengan Rp.1.500.000/bln. Tidak dijumpai kasus stunting pada keluarga yang memiliki penghasilan diatas Rp.1.500.000/bln. Hal ini berarti bahwa penghasilan keluarga turut menentukan hidangan yang disajikan untuk keluarga seharihari, baik kualitas maupun kuantitas makanan.

Masyarakat yang berpenghasilan rendah biasanya membelanjakan sebagian besar dari pendapatan untuk membeli makanan. Pendapatan juga menentukan jenis pangan yang akan dikonsumsi. Di negara yang berpendapatan rendah mayoritas pengeluaran pangan digunakan untuk membeli serealia, sedangkan di negara yang memiliki pendapatan per kapita tinggi pengeluaran untuk membeli bahan pangan protein meningkat (Annisa, 2012)

\section{Pengetahuan Ibu Mengenai Makanan Bergizi.}

Pengetahuan Pola asuh ibu merupakan perilaku ibu dalam mengasuh balita mereka. Perilaku sendiri berdasarkan dipengaruhi oleh sikap dan pengetahuan. Pengetahuan yang baik akan menciptakan sikap yang baik, yang selanjutnya apabila sikap tersebut dinilai sesuai, maka akan muncul perilaku yang baik pula.

Pada penelitian ini, responden dikelompokan menjadi dua kelompok, yaitu kelompok ibu yang memiliki pengetahuan tentang makanan bergizi dan kelompok ibu yang tidak memiliki pengetahuan tentang makanan bergisi. Gambaran responden terlihat pada Tabel 6. 
Tabel 6. Gambaran Pengetahuan Ibu tentang Makanan Bergizi

\begin{tabular}{lllllll}
\hline Apakah Ibu Pengetahuan & \multicolumn{2}{c}{ Stunting } & \multicolumn{2}{c}{ Normal } & \multicolumn{2}{c}{ Total } \\
\cline { 2 - 7 } Tentang Makanan Bergizi & $\mathbf{J m l}$ & $\mathbf{( \% )}$ & $\mathbf{J m l}$ & $\mathbf{( \% )}$ & $\mathbf{J m l}$ & $(\boldsymbol{\%})$ \\
\hline Mengetahui & 5 & 11.4 & 39 & 88.6 & 44 & 72.0 \\
Tidak mengetahui & 6 & 35.3 & 11 & 64.7 & 17 & 28.0 \\
\hline Total & $\mathbf{1 1}$ & $\mathbf{1 8 . 0}$ & $\mathbf{5 0}$ & $\mathbf{8 2 . 0}$ & $\mathbf{6 1}$ & $\mathbf{1 0 0 . 0}$ \\
\hline
\end{tabular}

Tabel 6 menunjukkan bahwa sebanyak $72 \%$ responden memiliki pengetahuan yang baik tentang makanan bergizi, sebaliknya $28 \%$ responden tidak memiliki pengetahuan yang baik tentang makanan bergizi. Kasus stunting lebih banyak dijumpai pada responden atau ibu yang tidak memiliki pengetahuan yang baik tentang makanan bergizi $(35,3 \%)$. Kasus stunting juga dijumpai pada Ibu yang memiliki pengetahuan tentang makanan bergizi, meskipun hanya $11,4 \%$. Kurangnya pengetahuan ini disebabkan karena minimnya informasi tentang makanan bergizi yang sampai kepada masyarakat di Kampung Arowi.

Sejalan dengan hal tersebut, Suhardjo (2003) menyatakan, salah satu penyebab gangguan gizi adalah kurangnya pengetahuan gizi dan kemampuan seseorang menerapkan informasi tentang gizi dalam kehidupan sehari-hari. Tingkat pengetahuan gizi ibu memengaruhi sikap dan perilaku dalam memilih bahan makanan, yang lebih lanjut akan memengaruhi keadaan gizi keluarganya

\section{Berat Badan Anak Saat Lahir}

Bayi Berat Lahir Rendah (BBLR) merupakan bayi baru lahir dengan berat badan saat lahir kurang dari 2.500 gram. BBLR tidak hanya dapat terjadi pada bayi prematur, tetapi juga pada bayi cukup bulan yang mengalami hambatan pertumbuhan selama kehamilan. Pada tahun 1961 oleh WHO semua bayi yang baru lahir dengan berat lahir kurang dari 2500 gram disebut bayi berat lahir rendah (WHO, 2018).

Tabel 7. Gambaran Berat Badan Anak Saat Lahir

\begin{tabular}{lcccccc}
\hline \multirow{2}{*}{$\begin{array}{c}\text { Berat Badan Anak Saat } \\
\text { Lahir }\end{array}$} & \multicolumn{2}{c}{ Stunting } & \multicolumn{2}{c}{ Normal } & \multicolumn{2}{c}{ Total } \\
\cline { 2 - 7 } & Jml & $\mathbf{( \% )}$ & Jml & $\mathbf{( \% )}$ & Jml & $(\%)$ \\
\hline BBLR <2500 gram & 4 & 50.0 & 4 & 50.0 & 8 & 13.1 \\
Normal & 7 & 13.2 & 46 & 86.8 & 53 & 86.9 \\
\hline Total & $\mathbf{1 1}$ & $\mathbf{1 8 . 0}$ & $\mathbf{5 0}$ & $\mathbf{8 2 . 0}$ & $\mathbf{6 1}$ & $\mathbf{1 0 0 . 0}$ \\
\hline
\end{tabular}

Berdasarkan Tabel 7, 86,9\% responden melehirkan anak dengan berat badan yang normal, hanya $13,1 \%$ responden yang anaknya masuk katagori Bayi Berat Lahir Rendah (BBLR). Kasus stunting pada bayi berkatagori BBLR cukup tinggi, yakni sekitar $50 \%$ atau separuhnya, sedangkan pada bayi normal hanya $13,2 \%$ yang mengalami stunting.
BBLR mencerminkan hasil perkembangan janin dan kecukupan gizi janin selama dalam kandungan. BBLR tidak hanya mempengaruhi kondisi bayi saat dilahirkan tetapi juga kesehatan bahkan kelangsungan hidupnya di masa depan.

Beberapa penelitian yang telah dilakukan juga menunjukan hal tersebut. Wiyogowati (2012) menyebutkan bahwa berat lahir memiliki dampak yang besar 
terhadap pertumbuhan, perkembangan dan tinggi badan anak selanjutnya. Bayi lahir dengan BBLR akan berisiko tinggi pada morbiditas, kematian, penyakit infeksi, kekurangan berat badan dan stunting diawal periode neonatal sampai masa kanak-kanak.

\section{Frekuensi Responden dalam Pemeriksaan Kehamilan}

Pada penelitian ini responden dikelompokan menjadi dua kelompok, yang pertama adalah responden yang jarang memeriksakan kehamilannya $(\leq 4$ Kali selama masa kehamilan), dan responden sering memeriksakan kehamilannya (> 4 Kali selama masa kehamilan). Berdasarkan pengakuan responden, $64 \%$ responden memeriksakan kehamilannya lebih dari 4 kali seperti pada Tabel 8.

Error! Reference source not found.Meskipun tidak terlalu jauh perbedaannya, data tersebut menunjukan bahwa kasus stunting lebih tinggi dijumpai pada ibu yang jarang memeriksakan kehamilannya (18,2\%). Rutin melakukan pemeriksaan kandungan adalah hal yang tidak kalah penting dalam mencegah stunting. Pemeriksaan rutin selama hamil bermanfaat untuk memastikan nutrisi yang dikonsumsi ibu hamil cukup dan mendeteksi jika ada komplikasi pada kehamilan. Semakin cepat diketahui, komplikasi kehamilan dapat semakin cepat diatasi.
Pemeriksaan selama kehamilan sangat perlu dilakukan yang bertujuan untuk mengoptimalkan kesehatan mental, fisik ibu maupun bayi. Manfaat pemeriksaan kehamilan, khususnya untuk ibu adalah supaya ibu mampu menghadapi persalinan, kala nifas, persiapan pemberian ASI dan kembalinya kesehatan reproduksi secara wajar (Manuaba, 1998). Pemeriksaan saat kehamilan adalah pelayanan yang bersifat preventif atau pencegahan untuk memantau kesehatan ibu dan mencegah komplikasi bagi ibu dan janin. Upaya yang harus dilakukan adalah mengupayakan wanita hamil harus sehat sampai persalinan, bilaman ada kelaianan fisik atau psikologis dapat diketahui dengan segera, dan ibu hamil dapat melahirkan tanpa penyulit (Bartini, 2012).

\section{Pemberian ASI Ekslusif.}

Pada penelitian ini responden dikatagorikan menjadi dua yaitu responden yang tidak memberikan ASI ekslusif dan responden yang memberikan ASI Ekslusif. Dikatan tidak ASI Ekslusif apabila anak mendaptkan asupan makanan dan minuman selain ASI selama 6 bulan pertama dan dikatakan ASI Ekslusif apabila anak hanya mendaptkan Air Susu Ibu (ASI) selama 6 bulan pertama. Berikut merupakan gambaran responden dalam memberikan ASI Ekslusif pada anak usia 6-23 bulan di Kampung Arowi Distrik Manokwari Timur.

Tabel 8. Gambaran Responden dalam memberikan ASI Ekslusif

\begin{tabular}{lcccccc}
\hline \multirow{2}{*}{$\begin{array}{c}\text { Apakah di berikan ASI } \\
\text { Ekslusif }\end{array}$} & \multicolumn{2}{c}{ Stunting } & \multicolumn{2}{c}{ Normal } & \multicolumn{2}{c}{ Total } \\
\cline { 2 - 7 } \multicolumn{1}{c}{ Jml } & $\mathbf{( \% )}$ & $\mathbf{J m l}$ & $\mathbf{( \% )}$ & $\mathbf{J m l}$ & $\mathbf{( \% )}$ \\
\hline ASI Ekslusif & 10 & 19.2 & 42 & 80.8 & 52 & 85.2 \\
Tidak ASI Eklusif & 1 & 11.1 & 8 & 88.9 & 9 & 14.8 \\
\hline Total & $\mathbf{1 1}$ & $\mathbf{1 8 . 0}$ & $\mathbf{5 0}$ & $\mathbf{8 2 . 0}$ & $\mathbf{6 1}$ & $\mathbf{1 0 0 . 0}$ \\
\hline
\end{tabular}


Pemberian Air Susu Ibu (ASI) Ekslusif adalah ASI yang diberikan kepada Bayi sejak dilahirkan selama enam bulan, tanpa menambahkan dan/atau menggantikan dengan makanan atau minuman lain. (kecuali obat, vitamin dan mineral). Sebagian besar responden $(85,2 \%)$ mengaku telah memberikan ASI ekslusif kepada bayinya, dan hanya $14,8 \%$ yang tidak memberikan ASI ekslusif pada anaknya. Kasus stunting dijumpai pada ibu yang memberikan ASI ekslusif sebanyak $19,2 \%$, sedangkan pada ibu yang tidak memberikan ASI ekslusif sebanyak $11,1 \%$.

Hasil ini sedikit berbeda dengan disertasi Fajrina (2016). Dalam disertasinya Fajrina menyatakan bahwa Balita yang tidak mendapatkan ASI dengan cukup berarti memiliki asupan gizi yang kurang baik dan dapat menyebabkan kekurangan gizi salah satunya dapat menyebabkan stunting. Dimana ASI mengandung kalsium yang lebih banyak dan dapat diserap tubuh dengan baik sehingga dapat memaksimalkan pertumbuhan terutama tinggi badan dan dapat terhindar dari resiko stunting.

Meskipun demikian, hal tersebut bukanlah hal yang aneh, sebab kandungan gizi dalam ASI juga tergantung dari asupan makanan dari sang ibu. Nurul, P (2010) menyatakan bahwa Ibu menyusui dengan gizi buruk akan mempengaruhi kecukupan ASI, karena tubuh membutuhkan zat gizi yang cukup untuk memproduksi ASI. Ada hubungan antara status gizi ibu menyusui dengan kecukupan ASI.

\section{Pemberian Makanan Pendamping ASI (MP_ASI)}

Setelah anak berusia 6 bulan, walaupun didalam ketentuan masih harus menyusu sampai usia 2 tahun, bayi memerlukan makanan pendamping agar pemenuhan gizi untuk tumbuh dapat terpenuhi. WHO/UNICEF dalam ketentuannya mengharuskan anak berusia 6-23 bulan memperoleh MP-ASI yang adekuat dengan ketentuan dapat menerima minimal 4 atau lebih dari 7 jenis makanan (serealia/umbi-umbian, kacangkacangan, produk olahan susu, telur dan sumber protein lainnya, sayur dan buah yang kaya vitamin A, sayur dan buah lainnya. Berdasarkan data, 93\% responden telah memberikan makanan pendamping ASI, dan hanya $7 \%$ yang tidak memberikan makanan pendamping ASI. Data selengkapanya dapat dilihat pada Tabel 9.

Tabel 9. Gambaran Responden dalam memberikan Makanan Pendamping ASI (MP_ASI)

\begin{tabular}{lcccccc}
\hline Apakah di Berikan Makanan & \multicolumn{2}{c}{ Stunting } & \multicolumn{2}{c}{ Normal } & \multicolumn{2}{c}{ Total } \\
\cline { 2 - 7 } Pendamping ASI (MP_ASI) & Jml & $\mathbf{( \% )}$ & Jml & $(\boldsymbol{\%})$ & Jml & $(\boldsymbol{\%})$ \\
\hline Memberikan MP-ASI & 10 & 17.5 & 47 & 82.5 & 57 & 93.0 \\
Tidak Memberikan MP-ASI & 1 & 25.0 & 3 & 75.0 & 4 & 7.0 \\
\hline Total & $\mathbf{1 1}$ & $\mathbf{1 8 . 0}$ & $\mathbf{5 0}$ & $\mathbf{8 2 . 0}$ & $\mathbf{6 1}$ & $\mathbf{1 0 0 . 0}$ \\
\hline
\end{tabular}

Berdasarkan Tabel 9, diketahui bahwa, dari $93 \%$ responden yang memberikan MP-ASI, dijumpai kasus stunting sebanyak $17,5 \%$. Jika dibandingkan responden yang tidak memberikan MPASI, maka angka stunting lebih rendah. Pada responden yang tidak memberikan MP-ASI, terdapat kasus stunting sebanyak 25\%. Anak-anak yang mendapat MP-ASI memiliki prevalensi stunting yang lebih rendah. Hal ini tentunya berkaitan dengan asupan gizi yang diperoleh selama masa tumbuh kembang anak.

Menurut Husaini (2001) tujuan pemberian makanan tambahan adalah untuk mencapai pertumbuhan dan perkem- 
bangan yang optimal, menghindari terjadinya kekurangan gizi, mencegah risiko malnutrisi, defisiensi mikronutrien. Anak mendapat makanan ekstra yang dibutuhkan untuk mengisi kesenjangan energi dengan nutrien, memelihara kesehatan, mencegah penyakit, memulihkan bila sakit, membantu perkembangan jasmani, rohani, psikomotor, mendidik kebiasaan yang baik tentang makanan dan memperkenalkan bermacam-macam bahan makanan yang sesuai dengan keadaan fisiologis bayi

\section{Gambaran Keikutsertaan KB saat ini di Wilayah Kampung Arowi Distrik Manokwari Timur Tahun 2020.}

Keikutsertaan ibu yang menggunakan KB untuk menjaga jarak anak agar ibu bisa mempunyai perhatian besar buat anaknya yang baru saja lahir atau tumbuh. Dalam penelitian ini, responden dibedakan dalam 2 kelompok, yaitu kelompok ibu yang menggunkan alat konstrasepsi (KB) dan kelompok ibu yang tidak menggunakan alat kontrasepsi. Berikut gambaran responden yang memiliki anak usia $0-24$ bulan dan menggunakan $\mathrm{KB}$ dan yang tidak menggunakan.

Tabel 10. Distribusi Responden Berdasarkan Keikutsertaan Ibu menggunakan Alat Kontrasepsi

\begin{tabular}{lcccccc}
\hline \multicolumn{1}{c}{$\begin{array}{c}\text { Ibu yang menggunakan KB } \\
\text { atau Alat Kontrasepsi }\end{array}$} & \multicolumn{2}{c}{ Stunting } & \multicolumn{2}{c}{ Normal } & \multicolumn{2}{c}{ Total } \\
\cline { 2 - 7 } & $\mathbf{J m l}$ & $\mathbf{( \% )}$ & $\mathbf{J m l}$ & $\mathbf{( \% )}$ & $\mathbf{J m l}$ & $(\boldsymbol{\%})$ \\
\hline Ber KB & 4 & 12.5 & 28 & 87.5 & 32 & 52.5 \\
Tidak Ber KB & 7 & 24.1 & 22 & 75.9 & 29 & 47.5 \\
\hline Total & $\mathbf{1 1}$ & $\mathbf{1 8 . 0}$ & $\mathbf{5 0}$ & $\mathbf{8 2 . 0}$ & $\mathbf{6 1}$ & $\mathbf{1 0 0 . 0}$ \\
\hline
\end{tabular}

Jumlah responden yang mengikuti program KB sebanyak 32 orang $(52,5 \%)$, sedangkan 29 orang responden $(47,5 \%)$ tidak mengikuti program KB (Tabel 10). Dari kedua kelompok tersebut, kasus stunting lebih banyak dijumpai pada kelompok ibu yang tidak mengukuti program KB $(24,1 \%)$, sedangkan kelompok ibu yang mengikuti program KB kasus stunting hanya $12,5 \%$. Keikutsertaan ibu dalam penggunaan alat kontrasepsi akan mempengaruhi jumlah anak dalam suatu keluarga. Besar jumlah anggota keluarga menentukan status gizi, namun status gizi juga ditentukan oleh faktor lain seperti dukungan keluarga dalam pemberian makanan bergizi serta tingkat sosial ekonomi keluarga.

Penelitian Fikadu, et al. (2014) di Ethiopia Selatan menunjukkan bahwa balita yang tinggal dengan jumlah anggota keluarga yang lebih banyak mempunyai risiko yang lebih tinggi terhadap kejadian stunting.

\section{Kelengkapan Imunisasi Anak}

Imunisasi adalah suatu cara untuk menimbulkan/meningkatkan kekebalan seseorang secara aktif terhadap suatu penyakit, sehingga bila kelak ia terpapar denganpenyakit tersebut tidak akan sakit atau sakit ringan. (Depkes RI, 2005). Kelengkapan imunisasi merupakan imunisasi yang diberikan kepada bayi seseuai dengan anjuran pemerintah yang disesuaikan menurut kelompok umur bayi.

Berdasarkan informasi dari responden, di ketahui bahwa $85,2 \%$ responden telah memberikan imunisasi kepada anaknya secara lengkap. Hanya $14,8 \%$ responden yang memberikan imunisasi secara tidak lengkap. Anakanak yang diberikan imunisasi secara lengkap, memiliki prevalensi stunting 
yang lebih rendah $(19,2 \%)$ dibandingkan dengan anak-anak yang diberikan imunisasi tidak lengkap $(22,2 \%)$.

Tabel 11. Gambaran Responden dalam memberikan Imunisasi

\begin{tabular}{lcccccc}
\hline \multirow{2}{*}{ Imunisasi Yang Diberikan } & \multicolumn{2}{c}{ Stunting } & \multicolumn{2}{c}{ Normal } & \multicolumn{2}{c}{ Total } \\
\cline { 2 - 7 } & $\mathbf{J m l}$ & $\mathbf{( \% )}$ & $\mathbf{J m l}$ & $\mathbf{( \% )}$ & $\mathbf{J m l}$ & $(\boldsymbol{\%})$ \\
\hline Lengkap & 10 & 19.2 & 42 & 80.8 & 52 & 85.2 \\
Tidak Lengkap & 2 & 22.2 & 7 & 77.8 & 9 & 14.8 \\
\hline Total & $\mathbf{1 1}$ & $\mathbf{1 8 . 0}$ & $\mathbf{5 0}$ & $\mathbf{8 2 . 0}$ & $\mathbf{6 1}$ & $\mathbf{1 0 0 . 0}$ \\
\hline
\end{tabular}

Riwayat imunisasi juga berpengaruh signifikan terhadap terjadinya stunting. Salimar, dkk. (2009) menyatakan bahwa kelengkapan imunisasi berpengaruh signifikan terhadap stunting. Penyebab adanya masalah kekurangan gizi, termasuk stunting, tidak hanya disebabkan oleh asupan makanan yang kurang, tetapi juga penyakit. Imunisasi akan memberikan kekebalan tubuh terhadap suatu penyakit dengan memasukkan sesuatu ke dalam tubuh agar tubuh tahan terhadap penyakit yang sedang mewabah atau berbahaya bagi seseorang. Dengan adanya imunisasi dapat mencegah pernyakit infeksi seperti TB, polio, difteri, pertusis, tetanus, campak, hepatitis, dan sebagainya.

\section{Penyakit Infeksi Pada Bayi}

Penyakit infeksi merupakan salah satu faktor penyebab langsung status gizi balita disamping konsumsi makanan.
Penyakit infeksi rentan terjadi dan sering dialami oleh balita. Dimana balita merupakan kelompok umur yang rawan gizi dan rawan penyakit, salah satu masalah yang sering dialami pada balita adalah infeksi cacing, diare dan ISPA. Dalam penelitian ini hanay akan diteliti dua penyakit infeksi yaitu diare dan ISPA.

Berikut merupakan gambaran penyakit infeksi yang pernah diderita oleh anak responden. 70,5\% responden mengaku anak mereka jarang mengalami sakit infeksi, sedangkan 29,5\% mengaku bayi mereka sering mengalami sakit infeksi. Berdasarkan data tersebut, prevalensi kasus stunting lebih banyak dijumpai pada bayi yang sering menderita sakit infeksi $(55,6 \%)$, sedangkan pada bayi yang jarang sakit infeksi, hanya dijumpai $2,3 \%$ kasus stanting. Data selengkapnya dapat dilihat pada Tabel 12 .

Tabel 12. Hasil Frekuensi Apakah Bayi Pernah Penyakit Infeksi Distribusi Karakteristik Responden

\begin{tabular}{lcccccc}
\hline Bayi pernah/sering menderita & \multicolumn{2}{c}{ Stunting } & \multicolumn{2}{c}{ Normal } & \multicolumn{2}{c}{ Total } \\
\cline { 2 - 7 } \multicolumn{1}{c}{ penyakit infeksi } & $\mathbf{J m l}$ & $\mathbf{( \% )}$ & $\mathbf{J m l}$ & $\mathbf{( \% )}$ & $\mathbf{J m l}$ & $(\boldsymbol{\%})$ \\
\hline Sering & 10 & 55.6 & 8 & 44.4 & 18 & 29.5 \\
Jarang & 1 & 2.3 & 42 & 97.7 & 43 & 70.5 \\
\hline Total & $\mathbf{1 1}$ & $\mathbf{1 8 . 0}$ & $\mathbf{5 0}$ & $\mathbf{8 2 . 0}$ & $\mathbf{6 1}$ & $\mathbf{1 0 0 . 0}$ \\
\hline
\end{tabular}

Penyakit infeksi berulang yang dialami sejak bayi menyebabkan tubuh anak selalu membutuhkan energi lebih untuk melawan penyakit. Jika kebutuhan 
ini tidak diimbangi dengan asupan yang cukup, anak akan mengalami kekurangan gizi dan akhirnya berujung dengan stunting.

Beberapa penyakit infeksi yang diderita bayi dapat menyebabkan berat badan bayi turun. Jika kondisi ini terjadi dalam waktu yang cukup lama dan tidak disertai dengan pemberian asupan yang cukupuntuk proses penyembuhan maka dapat mengakibatkan stunting (Pusat Data dan Informasi Kemenkes RI, 2013).

\section{Gambaran Sanitasi di Keluarga Responden.}

Sebagai masyarakat hendaknya kita harus paham manfaat jamban sehat dan bagaimana kriteria jamban yang baik serta pemeliharaannya. Syarat jamban sehat diantaranya seperti jamban tidak mencemari sumber air, tidak mencemari tanah disekitarnya, tidak berbau, tidak dapat dijangkau oleh serangga, mudah dibersihkan, penerangan yang cukup, lantai kedap air, ventilasi yang baik dan dilengkapi dinding dan atap pelindung.

Sementara prosedur untuk memelihara jamban yang sehat sebaiknya lantai jamban bersih dan kering, tidak ada serangga, tidak ada genangan air di sekitar jamban, tidak ada sampah berserakan dan tersedia alat pembersih, mencuci tangan menggunakan air mengalir/sabun, kejadian diare dengan kejadian stunting.

Tabel 13. Gambaran Kepemilikan Jamban pada Responden

\begin{tabular}{lllllll}
\hline & \multicolumn{2}{c}{ Stunting } & \multicolumn{2}{c}{ Normal } & \multicolumn{2}{c}{ Total } \\
\cline { 2 - 7 } Kepemilikan Jamban & $\mathbf{J m l}$ & $\mathbf{( \% )}$ & $\mathbf{J m l}$ & $\mathbf{( \% )}$ & $\mathbf{J m l}$ & $\mathbf{( \% )}$ \\
\hline Memili Jamban & 11 & 18.0 & 50 & 82.0 & 61 & 100.0 \\
Tidak Memiliki Jamban & 0 & 0.0 & 0 & 0.0 & 0 & 0.0 \\
\hline Total & $\mathbf{1 1}$ & $\mathbf{1 8 . 0}$ & $\mathbf{5 0}$ & $\mathbf{8 2 . 0}$ & $\mathbf{6 1}$ & $\mathbf{1 0 0 . 0}$ \\
\hline
\end{tabular}

Dari data yang diperoleh, semua responden memiliki jamban, tidak ada responden yang tidak memiliki jamban. Semua kasus stunting dijumpai pada rumah tangga yang memiliki jaman. Prevalensi kasus stunting tidak dapat dilihat dari kepemilikan jamban, karena kurangnya data pendukung.

\section{KESIMPULAN \\ Kesimpulan}

Berdasarkan hasil penelitian kasus stunting di Kampung Arowi, dapat diperoleh kesimpulan bahwa jumlah kasus stunting di Kampung Arowi Distrik Manokwari Timur mencapai $18 \%$ dari jumlah responden. Kasus stunting tertinggi dijumpai pada populasi responden yang memiliki pengetahuan tentang gizi yang rendah dan pada anak yang sering mengalami penyakit infeksi.

\section{Saran}

Perlunya edukasi terhadap masyarakat terutama ibu hamil, menyusui dan yang memiliki balita, secara intensif dilakukan pemerintah atau stakeholder dalam mengentaskan kasus stunting di Kampung Arowi. Kepada ibu yang memiliki anak balita sebaiknya untuk lebih peduli terhadap pola asuh dan penyakit infeksi pada anak.

\section{DAFTAR PUSTAKA}

Anisa, P., (2012). Faktor-faktor yang berhubungan dengan Kejadian Stunting Pada Balita Usia 25-60 Bulan di Kelurahan Kalibaru Depok Tahun 2012. Skripsi. Jakarta: Universitas Indonesia 
Bartini I. (2012). Asuhan Kebidanan Pada Ibu Hamil Normal. Yogyakarta: Nuha Medika Cebu, Philippines.

Fajrina, N. (2016). Hubungan Faktor Ibu dengan Kejadian Stunting pada Balita di Puskesmas Piyungan Kabupaten Bantul (Doctoral dissertation, Universitas' Aisyiyah Yogyakarta).

Fikadu, T., Assegid, S. \& Dube, L. (2014). Factor associated with stunting among children age 24 to 59 months in Meskan District, Gurage Zone, South Ethiopia: A case-control study. BMC Public Health, 14(800). Diakses dari http:// Www.biomedcentral.com/1471-2458/14/800.

Husaini, M, (2001). Makanan Bayi Bergizi. Cetakan VIII. Gadjah Mada, Yogyakarta.

Kemenkes RI. (2013). Riset Kesehatan Dasar; RISKESDAS. Jakarta: Balitbang Kemenkes RI.

Kementerian Kesehatan RI. (2016). INFODATIN Pusat Data dan Informasi Kementerian Kesehatan RI Situasi Balita Pendek. Jakarta Selatan.

Millennium Challenga Account. (2014). Dipetik Agustus 27, 2017, dari Stunting dan Masa Depan Indonesia info@mca-indonesia.go.id: www.mca-indonesia.go.id

Notoatmodjo, S. (2005). Promosi Kesehatan Teori dan Aplikasi. Jakarta: Rineka Cipta

Nurul Pujiastuti, (2010). Korelasi Antara Status Gizi Ibu Menyusui Dengan Kecukupan ASI di Posyandu Desa Karang Kedawang Kecamatan Sooko Kabupaten Mojokerto. Jurnal Keperawatan. Vol 1 no 2 Juli:126- 137 ISSN: 2086-3071

Salimar dkk, (2009). Karakteristik Masalah Pendek (Stunting) Pada Anak Balita di Seluruh Indonesia .
Jurnal Penelitian Gizi dan Makan, Suplemen : Bogor

Suhardjo. (2003). Berbagai cara pendidikan gizi. Jakarta: Bumi Aksara.

Wiyogowati, C. (2012). Kejadian Stunting Pada Anak Berumur di Bawah Lima Tahun (0-5 Bulan) di Provinsi Papua Barat Tahun 2010 (Analisis Data Riskesdas Tahun 2010). Skripsi Fakultas Kesehatan Masyarakat, Universitas Indonesia, Depok. 